\title{
An Analysis of the Relationship between Value Diversity and Project Implementation. A Case of Building Construction Projects in Kajiado County, Kenya, Africa.
}

\author{
Benson N. Leyian ${ }^{1}$, Charles M. Rambo ${ }^{1} \&$ Angeline Mulwa ${ }^{1}$ \\ ${ }^{1}$ Department of Management Science and Project Planning, University of Nairobi, Kenya \\ Correspondence: Benson N. Leyian, Department of Management Science and Project Planning, University of \\ Nairobi, Kenya. E-mail: ntoyianleyian@gmail.com
}

Received: September 23, 2021

Accepted: November 11, 2021

Online Published: November 11, 2021

doi:10.5539/jsd.v14n6p54

URL: https://doi.org/10.5539/jsd.v14n6p54

\begin{abstract}
The process of implementing building construction projects usually involves teams that are made up of individuals who are diverse in several aspects, which can be classified as either deep-level or surface-level diversity. Diversity in work-values has been seen to influence project performance in different fields. During the financial year 2016/2017, the County Government of Kajiado implemented a total of 50 building construction projects, which were meant to be completed within the financial year, but only $48 \%$ of the projects were deemed to be successfully implemented by the end of the period. Several factors have been attributed to the low success rate but none has looked at diversity in values among project team member. This research sought to determine the strength and nature of relationship between project team value diversity and building construction projects implementation process in Kajiado county. A pragmatic paradigm was employed in the research. Data was collected using semistructure questionnaires from a random sample of 251 respondents while interviews were done on 11 key respondents. Descriptive statistics such as percentages, means and standard deviations as well as inferential statistics like correlation and regression were generated from the quantitative data while qualitative data was thematically analysed. It was established that a moderate positive correlation $(r=0.401)$ existed between value diversity and project implementation process. It can therefore be inferred that value diversity positively influences the process of implementation of building construction projects.
\end{abstract}

Keywords: project team value diversity, interpersonal conflict, project implementation process

\section{Introduction}

Building construction infrastructure is fundamental to the development of economies globally. The last three decades have seen a rise in the need for the building construction projects so as to provide shelter for the growing population as well as housing offices and industries (Zhang, Xiaoling, Yuzhe, Liyin, and Martin, 2014). Building construction projects are usually designed to provide services for a long period of time, this therefore means the aspect of sustainability takes a prominent role during the entire project lifecycle (Haron et al., 2017). The process of implementing building construction projects takes the longest time in the entire lifecycle of the project and it is the key to the success of the project. It incorporates aspects of management of risks, definition of success and failure in the context of the project as well as the possible problems that can be encountered and possible outcomes (Avdeenko and Gilligan, 2015). Projects are made up of different stakeholders, therefore, successful implementation of a project might be defined differently by the different stakeholders. Van Niekerk and Steyn (2011) argue that an architect who designs a building views success from an aesthetic perspective, an engineer who is involved in implementing the plan views success of the project in terms of meeting the technical requirements, an accountant looks at it from the point of being completed within the budget, and the beneficiaries consider a project to be successfully implemented if it meets their needs.

Work-values can have an influence on the performance of the teams involved in project implementation. There have been mixed results with respect to the interactions between project team value diversity and implementation of construction projects. Liang et al. (2012) defined value diversity as the differences between project team members in terms of actions taken towards the achievement of the project goals or objectives based on their perception of work. Value diversity is better explained based on the similarity attraction paradigm, which postulates 
that individuals get attracted to people who are similar to them. This indicates that project team members will most likely be grouped based on the similarity in their work values. Values generally refer to the inbuilt beliefs that direct an individual towards rewards or away from punishment (Wiener, 1988), they are also used by researchers to basically describe and predict the behaviour of an individual in a work setting (Caldwell and O'Reilly, 1990). A study by Chou et al (2008) on shared work values and innovation among team members found a positive relationship between the two variables. They operationalized work value in terms of work ethics, norms, and rituals.

According to the shared mental model theory, when members of a project team have similar work values, those similar values lead to agreeable interpretations as well as harmonious opinions of the task they are expected to accomplish as a team (Cannon-Bowers and Salas, 2001). This implies that members who share the same work values have the same interpretation of the work environment hence they work towards the achievement of the same project goal. Research on deep level diversity in general and value diversity in particular are scanty, especially in the realm of building construction projects (Bell, 2007). According to the cognitive resource theory, project team value diversity leads to better performance since project team members share information easily. Tyran and Gibson (2008) define value diversity as a set of differences in behaviours and perspectives among individuals.

Since the introduction of devolved system of governance in Kenya in 2012, the country saw an exponential growth in the building construction industry, this was to meet the need that was brought about by introduction of county governments and decentralisation of several government offices. Kajiado county being one of the forty-seven counties in Kenya was not left behind in implementing building construction projects. In the financial year 2015/2016, the County Government of Kajiado implemented a total of 50 building construction projects, which were meant to be completed within that financial year, but only $48 \%$ of the projects were deemed to be successfully implemented by the end of the period. Several factors have been attributed to the low success rate but none has looked at diversity in values among project team member. This study sought to ascertain the influence of project team value diversity on the implementation of building construction projects which is a gap in knowledge. A plethora of studies on diversity have been done in developed countries, those in developing countries such as Kenya and looking at building construction projects in particular are scanty. Several studies done have been on surface-level variables, few have touched on deep-level diversity, this study sought to fill this gap in knowledge by establishing the influence of project team value diversity on the implementation of building construction projects as moderated by interpersonal conflicts in Kajiado county, Kenya.

\subsection{Implementation of Building Construction Projects}

The measures of the process of project implementation are many and diverse. According to Koops, Bosch-Rekveldt, Coman, Hertogh, and Bakker, (2016) a project is considered to be successfully implemented if it is done within the planned budget, scope, and time. However, Irimia-Dieguez, Medina-Lopez, and Alfalla-Luque, (2015) argue that the iron triangle components of time, budget, and scope cannot be conveniently used to measure project implementation. Project implementation is a variable, ambiguous, and complex part of the project lifecycle (Creasy and Anantatmula, 2013) making it so difficult to come up with specific metrics for measuring it. Referring to a project being implemented as being successful or otherwise, does not make sense without adequate quantification (De Wit, 1988). It is further argued by Morris (2010) that success in project implementation is a very slippery word, since it entirely relies on what is being measured, who is measuring it, and the measurement timeframe as well. Other researchers, such as, Albadvi, Farahani and Sheykh (2011) have added some other measurement aspects to the iron triangle measures of time, budget, and scope. They split project success factors into two broad groups, that is, the primary measures which include, time, client acceptance, quality, and cost while the secondary measures were, new opportunities that arise due to the project, a lack of disruptions to the life of the locals, and provision of strategic alignment.

A study done by Wolf and Hanisch (2014) on project implementation success measurement was divided into groups. A project that achieves more than $71 \%$ of its objectives is considered to be a high category project while one that averagely achieves less than $65 \%$ of its intended objectives is considered a low category project. This indicates that a project can achieve slightly more than half of its objectives but still be considered not to have been successfully implemented. In the United Kingdom, Gray (2000) reported that 44 project officials claimed that their projects were successfully implemented, but upon further investigation based on the common successful implementation measurement metrics, it was established that a paltry 14 out of all the 44 projects were found to be successfully implemented. This shows that there exists variance in what the criterion for measuring successfully implemented projects should entail.

Hartman and Ashrafi (2004) claim that it is important for those implementing a project and all stakeholders to 
come together and decide on the success metrics at the beginning of the project. Andersen (2012) supports the claim by arguing that stakeholders being key in a project means that their criterion of success is important, hence they should give a criterion for measurement of successful implementation of the project. It still remains unclear on whether the aspects of time, quality, and budget can be used independent of other measures to ascertain success in project implementation. Project stakeholders will always have different perceptions of success; therefore, determination of a success criterion should not be a by the way in project planning but it must be well planned and all stakeholders must agree on it (Hartley, 2003). The main stakeholders in the implementation of building construction projects in Kajiado county are the workers implementing the project, the project contractor, the county government officials, the national construction authority (NCA), the project consultant, and the loeal community residing where the project is being implemented. The project success measurement criterion is dependent on them.

A study done by Khosravi and Afshari (2011) rated time performance as the main metric followed by completion of the project within the planned cost, then quality performance, and client satisfaction came last. Project success remains an abstract notion, this means determination of project implementation success is very complex and highly subjective. It is argued by Baker et al. (2008) that there doesn't exist anything like absolute success in implementation of building construction projects, there is only perceived success. Building construction project implementation success is defined by Silva et al. (2016) as the perceived degree to which the predetermined performance objectives and stakeholder's expectations of the project have been achieved. In conclusion, to reliably measure success during project implementation, a criterion must be agreed on by all the project stakeholders and project implementation team before and at every stage of the project implementation. This view is supported by Koop et al. (2016) who argue that success in project implementation is pegged on the view of the project recipient. In this research successful project implementation is proposed to be measured in terms of completion within the planned budget, project meeting the quality specification of the client, project being completed within the planned time, as well as satisfaction of the clients with the project.

\subsection{Project Team Value Diversity and Implementation of Building Construction Projects}

Values according to Jehn (1994) are a set of beliefs that determine the way an individual behaves. It is a significant aspect that aids in understanding the attitudes and motivations of workers towards work. Hackman (1990) claims that value similarity in teams promotes interpersonal relation and reduces conflicts which can be beneficial to the process of project implementation. These claims are supported by Li et al (2009) who argue that values convergence in team members results in good working relations which in turn benefits project implementation, and Dose and Klimoski, (1999) add that individuals with similar values have confidence in one another and can interact well while working towards some set work objective. Values are considered to be an aspect of deep-level diversity. Studies on deep-level diversity operators are sparse. Bell (2007) specifically shows the existence of a dearth of studies looking at the relationship between value diversity and performance of teams, despite the role that values play in determining the attitudes and behaviours of workers towards work.

Among the few studies carried out on the effect of work value diversity on performance of teams, there exists substantial variability in the conceptualization as well as operationalization of values in addition to the outcomes of the association between value diversity and performance of teams. Fisher et al (1996) sought to establish and quantify the association between values agreement and team performance, they found a correlation coefficient of 0.64 between the two variables, indicating a strong positive correlation, this shows that convergence in values was key for the performance of teams. The study also established the existence of a linear relationship between values similarity and team performance. This conclusion is germane to the findings of Mullen and Copper (1994) who claimed that value cohesion among team members was instrumental in performance. Using a random sample of 306 participants extracted from 60 teams, Woehr, Arciniega, and Poling (2013) found that in general team value diversity had no significant influence on the performance of teams, but diversity with respect to the different dimensions of work value had a significant influence on the performance of team processes.

Team members with remarkedly divergent values may have different expectations and assumptions of each other's behaviour, making it hard to coordinate one another and arrive at a consensus (Kirkman and Shapiro, 2005). In a nutshell, team value diversity leads to an increase in team conflict which in turn results in a decrease in team effectiveness. Value diversity in teams may influence the attraction levels and members respect for each other, the ease with which team members communicate, as well as the level of obvious conflict in the team (McGrath et al., 1995). Unless there is congruence between values of team members and their task related skills, abilities, and knowledge, the primary effect of value diversity on team effectiveness is likely to be negative; diversity in team values causes tension and conflict and hence poor coordination (Jehn and Mannix, 2001). The similarity-attraction theory postulates that members in a team are likely to work together in harmony towards achievement of a common goal if they share the same values (Jehn et al., 1999). Byre (1971) claims that humans usually feel good when 
interacting with others whom they share values with. In workplace where the values of teams are so diverse, members of a team may not develop a shared identity for the team, instead they may identify with those with whom they share values and work towards excluding the considered outsider, this in turn will be detrimental to the productivity level of the team (Gaertner, Dovidio, Nier, Ward, \& Banker, 1999). Similarly, the informationprocessing theory suggest that team members with shared values have an almost similar interpretation of event in a work setting, this could be both beneficial and detrimental to the process of implementation of projects.

Research on the relationship between value diversity and performance have resulted in inconsistent results. On one hand, Jehn and Mannix, (2001) and Jehn et al., (1997) found a positive association between team value diversity and interpersonal conflict leading to a reduction in productivity levels of team members, while on the other hand, Harrison et al., (2002) found no significant association between team value diversity and performance. These inconsistent results call for a research to ascertain the effect of value diversity on the process of project implementation, especially in building construction projects.

\section{Theoretical Framework}

This study was premised on the Social Identity theory (SIT). It was first proposed by Tajfel and Turner (1978). According to the social identity theory, as part of the social identity process human beings show behaviours such as solidarity with people in their groups and discrimination towards people who do not belong to their groups. Individuals are bound to always subscribe to groups with attributes they feel motivates them and gives them some sense of belonging. Tajfel and Turner (1978) further argue that people put themselves into certain categories and others in different categories and place a lot of value in the categories, this is commonly referred to as social identity categorization.

Social Identity Theory works together with motivation. People will always find a reason that put them in a certain group. They don't just get into a group because it exists, but there must be some motivation which can either be interior or exterior. According to Dwivedula and Bredillet (2010), the interior motivation for joining a group comes from the ability of an individual being capable of meeting or achieving their own objectives, therefore, only those values that are similar to one's value will motivate them to join a group. Social Identity Theory suggests that people will move towards social groups that supplement their values, this creates a very strong emotional attachment to the social group (Gagne and Deci, 2005). Such affective attachment to social groups can either be beneficial or detrimental to the performance of teams. On a positive note, if a majority of the project team members share similar values, then they will be motivated to work as a group and achieve the project goals as expected (Hogg and Terry, 2001). On the contrary, if the project workers do not share the dominant group trait, negativity arises between them which may result in discrimination and exclusion (Foley et al., 2005).

\section{Conceptual Framework}

This study will be governed by the following relationship

\section{Independent Variable}

Value Diversity

○ Team member achievement

- Team member culture

- Team member integrity

- Team member work-ethics
Dependent Variable

Implementation of Building Construction Projects

- Project completion within time

- Project completion within budget

- Stakeholder satisfaction

○ Quality of project

$$
\begin{array}{ll}
\text { Interpersonal Conflicts } \\
\circ & \text { Task conflict } \\
\circ & \text { Relationship conflict }
\end{array}
$$

\section{Moderating Variable}

Figure 1. Conceptual framework 
In Fig. 1, there are three variables presented. Firstly, Implementation of building construction projects is the dependent variable, whose indicators are; project completion time, project cost, stakeholder satisfaction, and project quality. The second variable is the independent variable which is project team value diversity, whose indicators are; achievement of project team members, their cultural beliefs, integrity, and work-ethics. The last variable is the moderating variable which is Interpersonal conflict whose indicators are task conflict and relationship conflict.

\section{Research Methodology}

The study employed both descriptive and correlational research designs. Creswell (2011) defines a correlational research design as a design that can be used when a researcher seeks to determine the strength and nature of relationship between multiple variables while a descriptive research designs seeks to define the state of the phenomena as it is. In this research, descriptive will be used to describe the variables in the study in terms of percentages, means, and standard deviations, while the correlational design will explain the associations between the variables by use of correlations and regression. The target population for the study was 659 individuals divided into three parts, that is, 657 project workers, 1 projects engineer, and 1 projects manager. A random sample of 249 project workers was gotten from the target population, while the 1 projects manager and 1 projects engineer were purposively selected, making a total sample size of 251 . The instruments of data collection were interview guides and semi-structured questionnaires. The instruments were piloted in Nairobi County which borders Kajiado County and they share several characteristics with respect to the nature of projects being implemented and the respondents.

\section{Results and Discussion}

Data was collected, cleaned, and analyzed, and then the findings presented as per the following themes:

\subsection{Questionnaire Return Rate}

The researcher distributed 251 questionnaires to individuals involved in implementation of building construction projects in the expansive Kajiado County. A total of 235 questionnaires were returned by the study respondents for analysis. Fourteen (14) were found to be incomplete, and hence not usable for the study. This meant 221 questionnaires which translated to approximately $88.04 \%$ were used for the study. According to Saunders et al (2003) a response rate of between $30-50 \%$ is good enough for making statistical generalizations while Mugenda and Mugenda (2003) claims that a response rate that is greater than $70 \%$ is excellent. Based on the recommendation of Mugenda and Mugenda (2003), the study's response rate of $88.04 \%$ was excellent and hence sufficient for making statistical generalizations.

\subsection{Background Information of the Respondents}

The research collected some background data in the form of gender, age, level of education, and experience in building construction projects implementation from the study respondents. They are subsequently discussed in themes as follows:

\subsubsection{Gender of the Respondents}

Determination of the respondents' gender was to help establish the gender distribution of those involved in building construction projects implementation in Kajiado County. The results are shown in Table 1.

Table 1. Gender distribution of respondents

\begin{tabular}{lccr}
\hline Gender & Freq & C.F & Percent \\
\hline Male & 192 & 192 & 86.9 \\
Female & 29 & 221 & 13.1 \\
Total & 221 & & 100 \\
\hline
\end{tabular}

Table 1 shows that the dominant gender involved in the implementation of building construction projects is the male gender as depicted by $86.9 \%$, this can be credited to the fact that construction projects are mostly energy involving.

\subsubsection{Age Groups of the Respondents}

Age group determination was significant the dominant group involved in the project implementation process. The results are shown in Table 2. 
Table 2. Age distribution of respondents

\begin{tabular}{lccr}
\hline Age Group & Freq. & C.F & Percent \\
\hline $18-25$ & 13 & 13 & 5.9 \\
$26-30$ & 118 & 131 & 53.4 \\
$31-35$ & 42 & 173 & 19 \\
$36-40$ & 26 & 199 & 11.8 \\
$41-45$ & 13 & 212 & 5.9 \\
Over 45 & 9 & 221 & 4.1 \\
Total & 221 & & 100 \\
\hline
\end{tabular}

Table 2 shows that the bulk (53.4\%) of the people involved in the implementation of building construction projects lie in the age group $26-30$ years, followed by those in the age group $31-35$ years. These two groups contain young adults most of whom have cleared college in the Kenyan context and are job seeking.

\subsubsection{Education Level of the Respondents}

Determining the education level of the research respondents help the researcher to understand how the questions were responded to and how the variables were understood. Table 3 shows the results.

Table 3. Education level distribution of respondents

\begin{tabular}{lccr}
\hline Education level & Freq & C.F & Percent \\
\hline Primary & 45 & 45 & 20.4 \\
Secondary & 100 & 145 & 45.2 \\
Certificate in Building & 48 & 193 & 21.7 \\
Diploma & 28 & 221 & 12.7 \\
Total & 221 & & 100 \\
\hline
\end{tabular}

According to the results in Table 3, majority (79.6\%) of the research respondents had secondary level education and above. This indicates that majority of the respondents were capable of reading and understanding the questions asked and then providing relevant responses. In addition, educated workers are easier to give complex instructions which may sometimes be required during the process of project implementation.

\subsubsection{Experience of Respondents in the Building Construction Industry}

The years of experience that an individual has in the building construction projects is key since it reduces the time required for one to acquaint themselves with what happens during the implementation process. The experience level of the respondents is shown in Table 4.

Table 4. Experience level distribution of respondents

\begin{tabular}{lccr}
\hline Period worked & Freq. & C.F & Percent \\
\hline Less than 5 years & 63 & 63 & 28.5 \\
5-10 years & 105 & 168 & 47.5 \\
$10-15$ years & 36 & 204 & 16.3 \\
$15-20$ years & 13 & 217 & 5 \\
Over 20 years & 4 & 221 & 1.8 \\
Total & 221 & & 100.0 \\
\hline
\end{tabular}

Table 4 shows that majority of the study respondents $(71.5 \%)$ had been involved in the process of implementing building construction projects for more than 5 years. This shows that they have sufficient information regarding 
building construction projects implementation.

\subsection{Implementation of Building Construction Projects}

Building construction projects implementation was the dependent variable. It was operationalized by project completion time, project cost, stakeholder satisfaction, and project quality. The respondents were asked to give their opinion on questions regarding the constructs of implementation based on a 5-point Likert scale rating and the results are shown in Table 5.

Table 5. Implementation of building construction projects

\begin{tabular}{|c|c|c|c|c|c|c|c|c|}
\hline & Statements & SA & A & $\mathrm{N}$ & $\mathrm{D}$ & SD & Mean & $\begin{array}{l}\text { Std. } \\
\text { Dev }\end{array}$ \\
\hline \multirow[t]{2}{*}{1} & Tasks are usually completed in time & 64 & 132 & 10 & 6 & 9 & 4.07 & 0.90 \\
\hline & & $29.0 \%$ & $59.7 \%$ & $4.5 \%$ & $2.7 \%$ & $4.1 \%$ & & \\
\hline \multirow[t]{2}{*}{2} & Tasks are usually finished within the & 16 & 134 & 41 & 30 & 0 & 3.62 & 0.81 \\
\hline & & $7.2 \%$ & $60.6 \%$ & $18.6 \%$ & $13.6 \%$ & $0.0 \%$ & & \\
\hline \multirow[t]{2}{*}{3} & Reworks are usually minimum & 34 & 62 & 26 & 63 & 36 & 2.76 & 1.21 \\
\hline & & $15.4 \%$ & $28.1 \%$ & $11.7 \%$ & $28.5 \%$ & $16.3 \%$ & & \\
\hline \multirow[t]{2}{*}{4} & Quality of our work is good & 73 & 131 & 0 & 6 & 11 & 4.13 & 0.52 \\
\hline & & $33.0 \%$ & $59.3 \%$ & $0.0 \%$ & $2.7 \%$ & $5.0 \%$ & & \\
\hline \multirow[t]{2}{*}{5} & Materials are usually checked for quality & 80 & 120 & 6 & 9 & 6 & 4.07 & 0.91 \\
\hline & & $36.2 \%$ & $54.3 \%$ & $2.7 \%$ & $4.1 \%$ & $2.7 \%$ & & \\
\hline \multirow[t]{3}{*}{6} & Our client is generally satisfied with our & 72 & 134 & 4 & 5 & 6 & 4.22 & 0.81 \\
\hline & work & $32.6 \%$ & $60.6 \%$ & $1.8 \%$ & $2.3 \%$ & $2.7 \%$ & & \\
\hline & Composite Mean and Std. Dev. & & & & & & 3.87 & 0.48 \\
\hline
\end{tabular}

According to Table 5, statement 1, that tasks are usually completed in time, out of the 221 respondents, those who strongly agreed were 64(29\%), those who agreed were 132(59.7\%), those who were not sure, that is neither agreed or disagreed with the statement were $10(4.5 \%)$, those who disagreed were $6(2.7 \%)$, while those who strongly disagreed were $9(4.1 \%)$. The statement mean was 4.07 , which indicates that the respondents agreed with the statement. However, the line item 1 standard deviation of 0.90 is larger than the composite standard deviation of 0.48 , showing the existence of variations in the responses.

Statement 2, that tasks are completed within budget, out of the 221 respondents, those who strongly agreed were $16(7.2 \%)$, those who agreed were 134(60.6\%), those who were not sure with the statement were 41(18.6\%), those who disagreed were $30(13.6 \%)$, while those who strongly disagreed were $0(0.0 \%)$. The statement mean was 3.62 , which indicates that the respondents neither agreed nor disagreed with the statement. However, the line item 2 standard deviation of 0.81 is larger than the composite standard deviation of 0.48 , showing the existence of divergent views with regard to the statement.

On statement 3 , that reworks are usually minimum, out of the 221 respondents, those who strongly agreed were $34(15.4 \%)$, those who agreed were 62(28.1\%), those who were not sure with the statement were $26(11.7 \%)$, those who disagreed were $63(28.5 \%)$, while those who strongly disagreed were $36(16.3 \%)$. The statement mean was 2.76 , which indicates that the respondents disagreed with the statement, this points towards the existence of several reworks during the implementation process. However, the line item 3 standard deviation of 1.21 is larger than the composite standard deviation of 0.48 , showing the existence of big differences in the respondents' opinions.

On statement 4 , that quality of our work is good, out of the 221 respondents, those who strongly agreed were $73(33.0 \%)$, those who agreed were $133(59.3 \%)$, those who were not sure with the statement were $0(0.0 \%)$, those who disagreed were $6(2.7 \%)$, while those who strongly disagreed were $11(5.0 \%)$. The statement mean was 4.13 , which indicates that the respondents agreed with the statement. The line item 4 standard deviation of 0.52 is slightly larger than the composite standard deviation of 0.48 , showing convergence of views with regard to the statement. 
Statement 5, that materials are usually checked for quality, out of the 221 respondents, those who strongly agreed were $80(36.2 \%)$, those who agreed were $120(54.3 \%)$, those who were not sure with the statement were $6(2.7 \%)$, those who disagreed were $9(4.1 \%)$, while those who strongly disagreed were $6(2.7 \%)$. The statement mean was 4.07, which indicates that the respondents agreed with the statement. However, the line item 5 standard deviation of 0.91 is larger than the composite standard deviation of 0.48 , showing the existence of divergent views with regard to the statement.

On statement 6 , that our client is satisfied with our work, out of the 221 respondents, those who strongly agreed were $72(32.6 \%)$, those who agreed were $134(60.6 \%)$, those who were not sure with the statement were $4(1.8 \%)$, those who disagreed were $5(2.3 \%)$, while those who strongly disagreed were $6(2.7 \%)$. The statement mean was 4.22, which indicates that the respondents strongly agreed with the statement. However, the line item 6 standard deviation of 0.91 is greater than the composite standard deviation of 0.48 , showing divergence in opinions with regard to the statement.

Lastly, the composite mean of building construction projects implementation was 3.87 with a standard deviation of 0.48 , this shows that the respondents agreed that the project they were implementing was generally successfully.

Site engineers and project managers were asked about the indicators of implementation with respect to their projects in an interview and this is what they said; regard completion of projects within the planned time

"I have been involved in implementation of several project sponsored by the county government, and a very small percentage have had a time overrun. Like this one will be completed even before the planned time because we have everything available." (PM 1).

Another project manager said,

"This project will not be completed as expected, the duration we had initially anticipated was not enough, so we have to go beyond the planned time." (PM 5)

With regard to project cost, this is what they said,

"I feel this project was not well budgeted for; they did not factor in the high rate of inflation in the country. The County government will have to add some money for the project to be completed." (Site Engineer 4)

Regarding satisfaction of the client, one of the respondents said,

"The county government is very happy with the progress we are making in this school dormitory project, and even in the projects I have done for them, they have been satisfied with the quality of the final product. That is why they always give me projects to implement for them." (Site Engineer 2).

\subsection{Project Team Value Diversity and Implementation of Building Construction Projects}

The research sought to determine the association between project team value diversity and implementation of building construction projects in Kajiado county. The respondents were required to give their opinions based on a Likert scale of $1-5$ on items regarding value diversity, where; 5 - Strongly Agree, 4 - Agree, 3 - Neutral, 2 Disagree and 1 - Strongly Disagree. The results are shown in Table 6. 
Table 6. Project team value diversity and implementation of building construction projects

\begin{tabular}{|c|c|c|c|c|c|c|c|c|}
\hline & Statement & SA & $\mathbf{A}$ & $\mathbf{N}$ & D & SD & Mean & $\begin{array}{l}\text { Std. } \\
\text { Dev. }\end{array}$ \\
\hline \multirow[t]{2}{*}{1} & Achievement is rewarded & 81 & 21 & 37 & 78 & 4 & 3.44 & 1.34 \\
\hline & & $36.7 \%$ & $9.5 \%$ & $16.7 \%$ & $35.3 \%$ & $1.8 \%$ & & \\
\hline \multirow[t]{2}{*}{2} & Diverse personality exists & 33 & 153 & 8 & 0 & 27 & 3.75 & 1.11 \\
\hline & & $14.9 \%$ & $69.2 \%$ & $3.7 \%$ & $0.0 \%$ & $12.2 \%$ & & \\
\hline \multirow[t]{2}{*}{3} & Different cultures are & 92 & 117 & 8 & 4 & 0 & 4.34 & 0.64 \\
\hline & accommodated & $41.6 \%$ & $52.9 \%$ & $3.7 \%$ & $1.8 \%$ & $0.0 \%$ & & \\
\hline \multirow[t]{2}{*}{4} & Project members are true to their & 98 & 119 & 4 & 0 & 0 & 4.43 & 0.53 \\
\hline & values & $44.4 \%$ & $53.8 \%$ & $1.8 \%$ & $0.0 \%$ & $0.0 \%$ & & \\
\hline \multirow[t]{2}{*}{5} & I always keep my promises & 116 & 99 & 4 & 2 & 0 & 4.49 & 0.59 \\
\hline & & $52.6 \%$ & $44.8 \%$ & $1.8 \%$ & $0.9 \%$ & $0.0 \%$ & & \\
\hline \multirow[t]{2}{*}{6} & $\begin{array}{l}\text { I believe honesty is the basis for } \\
\text { trust }\end{array}$ & 93 & 120 & 0 & 4 & 4 & 4.33 & 0.74 \\
\hline & & $42.1 \%$ & $54.3 \%$ & $0.0 \%$ & $1.8 \%$ & $1.8 \%$ & & \\
\hline \multirow[t]{2}{*}{7} & There is good teamwork and & 64 & 127 & 20 & 10 & 0 & 4.11 & 0.74 \\
\hline & cooperation in the project & $29.0 \%$ & $57.5 \%$ & $9.0 \%$ & $4.5 \%$ & $0.0 \%$ & & \\
\hline \multirow[t]{2}{*}{8} & $\begin{array}{l}\text { Project members motivate each } \\
\text { other to come up with efficient }\end{array}$ & 71 & 98 & 4 & 48 & 0 & 3.87 & 1.09 \\
\hline & ways of doing work & $32.1 \%$ & $44.4 \%$ & $1.8 \%$ & $21.7 \%$ & $0.0 \%$ & & \\
\hline \multirow[t]{2}{*}{9} & Project members encourage each & 44 & 169 & 4 & 4 & 0 & 4.14 & 0.52 \\
\hline & other at work & $19.9 \%$ & $76.5 \%$ & $1.8 \%$ & $1.8 \%$ & $0.0 \%$ & & \\
\hline \multirow[t]{2}{*}{10} & We engage in team building & 88 & 120 & 9 & 4 & 0 & 4.32 & 0.64 \\
\hline & activities in this project & $39.8 \%$ & $54.3 \%$ & $4.1 \%$ & $1.8 \%$ & $0.0 \%$ & & \\
\hline \multirow[t]{2}{*}{11} & Project members listen to each & 53 & 157 & 7 & 4 & 0 & 4.17 & 0.56 \\
\hline & otner & $24.0 \%$ & $71.0 \%$ & $3.2 \%$ & $1.8 \%$ & $0.0 \%$ & & \\
\hline \multirow[t]{3}{*}{12} & All individual differences are & 103 & 109 & 5 & 4 & 0 & 4.41 & 0.63 \\
\hline & respected in the project & $46.6 \%$ & $49.3 \%$ & $2.3 \%$ & $1.8 \%$ & $0.0 \%$ & & \\
\hline & Composite Mean and Std. Dev. & & & & & & 4.15 & 0.43 \\
\hline
\end{tabular}

Table 6 shows that data collected from the respondents with regard to statements making up project team value diversity. Statement 1 that achievement is rewarded, the results indicated that $81(36.7 \%)$ respondents strongly agreed, $21(9.5 \%)$ agreed, $37(16.7 \%)$ were not sure, $78(35.3 \%)$ disagreed while $4(1.8 \%)$ strongly disagreed. The mean score was 3.44 and a standard deviation of 1.34 indicating that majority of respondents agreed with the statement though their responses were varied as shown by a high standard deviation value. Hence, in building 
construction projects in Kajiado County, it can be assumed that achievements are usually rewarded.

The second statement was that diverse personality differences exist. Based on this, 33(14.9\%) respondents strongly agreed, 153(69.2\%) agreed, 8(3.6\%) were not sure, and 27(12.2\%) strongly disagreed. The mean response attained was 3.75 with a standard deviation of 1.11, this shows that the respondents were in agreement with the given statement. It is therefore concluded that there exist differences in personality differences between project team members in building construction projects in Kajiado County.

On statement 3, that different cultures are accommodated. The results show that, 92(41.6\%) respondents strongly agreed, $117(52.9 \%)$ agreed, $8(3.6 \%)$ were not sure while $4(1.8 \%)$ disagreed. The mean score was 4.34 with a standard deviation of 0.64 , indicating that respondents strongly agreed with the statement. This can be inferred to imply that building construction projects in Kajiado county comprise of workers from different cultural backgrounds.

Statement 4 that project team members were true to their values. Based on this, 98(44.3\%) of the respondents strongly agreed, $119(53.8 \%)$ agreed while $4(1.8 \%)$ were not sure. The mean for the item was 4.43 with a standard deviation of 0.53 , showing that respondents strongly agreed to the statement. Hence team member believed in their values.

On statement 5 that project team members kept their promises. The results showed that $116(52.5 \%)$ respondents strongly agreed, $99(44.8 \%)$ agreed, $4(1.8 \%)$ were not sure, $2(0.9 \%)$ disagreed while $4(1.8 \%)$ strongly disagreed. The mean score was 4.49 and standard deviation was 0.59 , this shows that the respondents strongly agreed with the statement.

Statement 6 that honesty was the basis for trust among project team members. Based on this, 93(42.1\%) respondents strongly agreed, $120(54.3 \%)$ agreed, $4(1.8 \%)$ disagreed and 4(1.8\%) strongly disagreed. The mean score was 4.33 and a standard deviation of 0.74 , indicating that the respondents strongly agreed that honesty was the basis for trust among project team members.

On statement 7 that teamwork and cooperation existed among project team members. The results showed that $64(29 \%)$ strongly agreed, $127(57.5 \%)$ agreed, $20(9 \%)$ were not sure and $10(4.5 \%)$ disagreed with the item. The mean score was 4.11 with a standard deviation of 0.74 , this shows that respondents were in agreement with the item showing that team work and cooperation existed among the project team members in Kajiado County.

Statement 8 , that project team members motivate each other to come up with efficient ways of doing work. The results indicated that $71(32.1 \%)$ of the respondents strongly agreed, $98(44.3 \%)$ agreed, $4(1.8 \%)$ were not sure while $48(21.7 \%)$ disagreed with the statement. The mean score was 3.87 and standard deviation was 1.09 , showing that respondents agreed with the statement.

Statement 9 that project team members encouraged each other at work, the results showed that $44(19.9 \%)$ respondents strongly agreed, $169(76.5 \%)$ agreed, $4(1.8 \%)$ were not sure, and $4(1.8 \%)$ disagreed. The mean attained was 4.14 with a standard deviation of 0.52 , this indicates that the respondents agreed with the statement. Hence, it shows that project team members encouraged each other at the project sites.

On statement 10 , that we encourage team building activities in the projects. The results show that $88(39.8 \%)$ respondents strongly agreed, $120(54.3 \%)$ agreed, $9(4.1 \%)$ were not sure and $4(1.8 \%)$ disagreed with the statement. The mean score was 4.32 with a standard deviation of 0.64 , showing that the respondents strongly agreed with the statement. Hence, it can be concluded that team building is usually done in building construction projects in Kajiado County. However, high variations exist as shown by the difference between the line item and composite standard deviations.

Statement 11 that project team members listen to each other opinions. Based on this, 53(24\%) respondents strongly agreed, $157(71 \%)$ agreed, $7(3.2 \%)$ were not sure while $4(1.8 \%)$ disagreed with the statement. The mean score was 4.17 and a standard deviation of 0.56 . This indicates that the respondents were in agreement with the item. However, a high line standard deviation of 0.56 than the composite standard deviation of 0.43 indicates divergent views.

Statement 12 individual differences were respected in the project. Based on this, 103(46.6\%) respondents strongly agreed, 109(49.3\%) agreed, 5(2.3\%) were not sure, while 4(1.8\%) disagreed. The mean score was 4.41 and a standard deviation of 0.63 , showing strong agreement with the statement. This therefore, shows that the respondents strongly agreed that individual differences were respected. However, there is variation in responses as shown by a high line item standard deviation of 0.63 as compared to the composite standard deviation of 0.43 .

Lastly, the composite mean for value diversity was found to be 4.15 with a standard deviation of 0.43 , this shows that the respondents strongly agreed with the statement on value diversity and it can therefore, be inferred that 
value diversity influences the process of implementation of building construction projects in Kajiado County.

In depth interviews were also conducted. When asked about the significance of value diversity in project teams, one site engineer gave the following response:

"I prefer working with individual who have religious values instilled in them, people who cannot steal materials, people who work because they have come to work to earn a living, and not people who want to be followed every time so as to do what is expected of them." (Engineer 3)

Another site engineer said:

"When recruiting people to work with, I make sure I get to understand what they stand for, what their opinion towards others are, and generally what is their view of work. In so doing I get understand the values of the individual well before incorporating them in my working team." (Engineer 2)

5.4.1 Correlational Analysis of Project Team Value Diversity and Implementation of Building Construction Projects

Correlational analysis using the Pearson method was done to establish the strength and direction of relationship between project team value diversity and implementation of building construction projects. The findings are presented in Table 7.

Table 7. Correlation between value diversity and implementation of building construction projects

\begin{tabular}{|c|c|c|c|}
\hline \multicolumn{3}{|l|}{ Variable } & \multirow{2}{*}{$\frac{\text { Project Team Value Diversity }}{0.401^{*}}$} \\
\hline Implementation & Building & Pearson Correlation & \\
\hline \multirow[t]{2}{*}{ Construction Projects } & & Sig. (2-tailed) & 0.000 \\
\hline & & $\mathrm{n}$ & 221 \\
\hline
\end{tabular}

* Correlation is significant at the 0.05 level (2-tailed)

Table 7 gives a Pearson correlation coefficient of 0.401 , with a p-value of $0.000<0.05$. This shows that the correlation coefficient is statistically significant. The coefficient shows the existence of a positive association between the process of implementation of building construction projects and value diversity in project teams, which is statistically significant. Therefore, some moderate level of diversity in values among project team members has a positive influence on the implementation of building construction projects. This finding is in line with the findings of Li et al., (2009) and Zhou et. al., (2017) who argued that values play an important role in team member relationships and team success.

5.4.2 Regression Analysis of Project Team Value Diversity on Implementation of Building Construction Projects

The research sought and generated regression equation on contribution of project team value diversity on the implementation of building construction projects. This led to a regression model whose coefficients are discussed in the subsequent sub-themes.

5.4.2.1 Model Summary of Regression of Project Team Value Diversity and Implementation of Building Construction Projects

The model summary sought to determine how project team value diversity as predictor significantly or insignificantly predicted implementation of building construction projects. The regression model summary is presented in Table 8. 
Table 8 . Model summary of value diversity and implementation of building construction projects

\begin{tabular}{|c|c|c|c|c|c|c|c|c|c|}
\hline \multicolumn{10}{|c|}{ Model Summary } \\
\hline \multirow[b]{2}{*}{ Model } & \multirow[b]{2}{*}{$\mathrm{R}$} & \multirow[b]{2}{*}{ R Square } & \multirow[b]{2}{*}{$\begin{array}{l}\text { Adjusted R } \\
\text { Square }\end{array}$} & \multirow[b]{2}{*}{$\begin{array}{l}\text { Std. Error of } \\
\text { the Estimate }\end{array}$} & \multicolumn{5}{|c|}{ Change Statistics } \\
\hline & & & & & $\begin{array}{c}\text { R Square } \\
\text { Change }\end{array}$ & F Change & df1 & $\mathrm{df} 2$ & $\begin{array}{l}\text { Sig. F } \\
\text { Change }\end{array}$ \\
\hline 1 & $0.401^{\mathrm{a}}$ & 0.161 & 0.157 & 0.5075 & 0.161 & 41.877 & 1 & 219 & 0.000 \\
\hline
\end{tabular}

Table 8 of the model summary shows that there was a moderate positive correlation $(R=0.401)$ between project team value diversity and implementation of building construction projects with those predicted by the regression model. In addition, $16.1 \%$ of the variation in the implementation of building construction projects was explained by project team value diversity while the remaining $83.9 \%$ is explained by other variables not in the model.

5.4.2.2 ANOVA of Regression of Project team Value Diversity and Implementation of Building Construction Projects.

The study aimed at establishing if the regression model was best match for predicting implementation of building construction projects after employing project team value diversity. The results of the regression coefficient are presented in Table 9.

Table 9. ANOVA of regression of value category and implementation of building construction projects

\begin{tabular}{llccccc}
\hline \multicolumn{7}{c}{ ANOVA } \\
\hline Model & \multicolumn{7}{c}{ Sum of Squares } & df & Mean Square & F & Sig. \\
\hline 1 & Regression & 10.787 & 1 & 10.787 & 41.877 & $.000^{\mathrm{b}}$ \\
& Residual & 56.413 & 219 & .258 & & \\
& Total & 67.201 & 220 & & & \\
\hline \multicolumn{7}{l}{ a. Dependent Variable: Implementation of Building Construction Projects } \\
\hline
\end{tabular}

The ANOVA results on Table 9 point out that F-statistic $(1,219)=41.877$ is significant at $p$ - value $0.000<0.05$ indicating that the predictor coefficient was at least not equal to zero and hence the regression model results were a better prediction of implementation of building construction projects after use of project team value diversity. The findings on project team value diversity are in tandem with studies by Chou et al. (2008) observed that similarities in the values of team members may lead to a lower degree of relationship conflict, higher group identification, and more social integration this in turn was seen to enhance the performance of the organization. Another study by Liang et al. (2012) found out that team members with shared work ethics were willing to follow teamwork norms, sort their differences out with ease, and reduce any tensions during interpersonal interactions and hence work together towards the success of the project implementation process.

However, the study contradicted the findings of Liang et al. (2007) who posited that when team members have different values, friction results and increases the extent of relationship conflict among team members, which leads to deterioration of the working relationship hence leading to low performance. Further, diverse values add to conflicts about how to conduct tasks and in the perception of team goals (Liang et al., 2007).

5.4.2.3 Regression Coefficient of Project Team Value Diversity and Implementation of Building Construction Projects

The study sought to establish whether there was influence of project team value diversity on implementation of building construction projects. The regression coefficient results are presented in Table 10. 
Table 10. Regression analysis of project team value and implementation of building construction projects

\begin{tabular}{|c|c|c|c|c|c|c|}
\hline \multicolumn{7}{|c|}{ Coefficient } \\
\hline \multirow[t]{2}{*}{ Model } & & \multicolumn{2}{|c|}{ Unstandardized Coefficients } & $\begin{array}{r}\text { Standardized } \\
\text { Coefficients }\end{array}$ & \multirow[t]{2}{*}{$\mathrm{t}$} & \multirow[t]{2}{*}{ Sig. } \\
\hline & & B & Std. Error & Beta & & \\
\hline \multirow[t]{4}{*}{1} & (Constant) & 1.748 & 0.332 & & 5.260 & 0.000 \\
\hline & Project & 0.515 & 0.080 & 0.401 & 6.471 & 0.000 \\
\hline & Team Value & & & & & \\
\hline & Diversity & & & & & \\
\hline
\end{tabular}

a. Dependent Variable: Implementation of Building Construction Projects

The regression results in Table 10 give the terms $\left(\beta_{0}=1.748, p<0.05\right)$ and project team value diversity $\left(\beta_{1}=\right.$ $0.515, p<0.05)$ which are all statistically significant. This leads to establishment of a regression equation of implementation of building construction projects on project team value diversity given by $Y=1.748+0.515 X_{3}$ showing that for each unit increase in project team value diversity, implementation of building construction projects is marginally transformed by 0.515 units. It was therefore, concluded that project team value diversity and implementation of building construction projects are positively and linearly related.

\section{Conclusion}

The purpose of the study was to determine the relationship that exists between value diversity in project teams and the process of implementation of building construction projects in Kajiado County. Project team value diversity was operationalised as team member achievements, culture, integrity, and work-ethics. it was established that there exists a moderate positive correlation between project team value diversity and implementation of building construction projects.

\section{Recommendation}

The study findings established that project team value diversity has a moderate positive influence on implementation of building construction projects. The study therefore recommends that project recruitment officers should make sure that the project team comprises of individuals who are moderately diverse in terms of values so as the help improve the process of building construction projects implementation.

\section{Limitations}

The study collected data on the two variables of value diversity among project team members and the implementation of building construction projects in Kajiado county, Kenya. The county covers a large geographical area and the building projects implemented by the Kajiado county government are spread across the entire county, the researcher only sampled projects that could be accessed easily due to the remote nature of some areas of the county. Additionally, some respondents could have felt the nature of data being sought was sensitive hence hiding some information even after being assured of their anonymity in the entire research.

\section{References}

Ahsan, K., \& Gunawan, I. (2010). Analysis of cost and schedule performance of international development projects. International Journal of Project Management, 28(1), 68-78. https://doi.org/10.1016/j.ijproman.2009.03.005

Barclay, C., \& Osei-Bryson, K.-M. (2010). Project performance development framework: An approach for developing performance criteria \& measures for information systems (IS) projects. International Journal of Production Economics, 124(1), 272-292. https://doi.org/10.1016/j.ijpe.2009.11.025

Bell, S. T. (2007). Deep-level composition variables as predictors of team performance: a meta-analysis. Journal of Applied Psychology, 92(3), 595. https://doi.org/10.1037/0021-9010.92.3.595

Bhattacherjee, A. (2012). Social science research: Principles, methods, and practices.

Bodla, A. A., Tang, N., Jiang, W., \& Tian, L. (2018). Diversity and creativity in cross-national teams: The role of team knowledge sharing and inclusive climate. Journal of Management \& Organization, 24(5), 711-729. https://doi.org/10.1017/jmo.2016.34

Chan, A. P., Chan, D. W., Chiang, Y. H., Tang, B.-S., Chan, E. H., \& Ho, K. S. (2004). Exploring critical success 
factors for partnering in construction projects. Journal of Construction Engineering and Management, 130(2), 188-198. https://doi.org/10.1061/(ASCE)0733-9364(2004)130:2(188)

Chan, A. P., Ho, D. C., \& Tam, C. M. (2001). Design and build project success factors: Multivariate analysis. Journal of Construction Engineering and Management, 127(2), 93-100. https://doi.org/10.1061/(ASCE)0733-9364(2001)127:2(93)

Chan, A. P., Ma, X., Yi, W., Zhou, X., \& Xiong, F. (2018). Critical review of studies on building information modeling (BIM) in project management.

Diallo, A., \& Thuillier, D. (2004). The success dimensions of international development projects: The perceptions of African project coordinators. International Journal of Project Management, 22(1), $19-31$. https://doi.org/10.1016/S0263-7863(03)00008-5

Dose, J. J., \& Klimoski, R. J. (1999). The diversity of diversity: Work values effects on formative team processes. Human Resource Management Review, 9(1), 83-108. https://doi.org/10.1016/S1053-4822(99)00012-1

Durdyev, S., Omarov, M., \& Ismail, S. (2017). Causes of delay in residential construction projects in Cambodia. Cogent Engineering, 4(1), 1291117. https://doi.org/10.1080/23311916.2017.1291117

Dwivedula, R., \& Bredillet, C. N. (2010). Profiling work motivation of project workers. International Journal of Project Management, 28(2), 158-165. https://doi.org/10.1016/j.ijproman.2009.09.001

Foley, S., Hang-Yue, N., \& Wong, A. (2005). Perceptions of discrimination and justice: Are there gender differences in outcomes? Group \& Organization Management, 30(4), 421-450. https://doi.org/10.1177/1059601104265054

Freeman, M., \& Beale, P. (1992). Measuring project success.

Gagné, M., \& Deci, E. L. (2005). Self - determination theory and work motivation. Journal of Organizational behavior, 26(4), 331-362. https://doi.org/10.1002/job.322

Gong, Y., Kim, T.-Y., Lee, D.-R., \& Zhu, J. (2013). A multilevel model of team goal orientation, information exchange, and creativity. Academy of Management Journal, 56(3), 827-851. https://doi.org/10.5465/amj.2011.0177

Hackman, J. R. (1990). Groups that work and those that don't. Jossey-Bass.

Hogg, M. A., \& Terry, D. J. (2001). Social identity theory and organizational processes.

Jehn, K. A. (1994). Enhancing effectiveness: An investigation of advantages and disadvantages of value - based intragroup conflict. International Journal of Conflict Management. https://doi.org/10.1108/eb022744

Jehn, K. A. (1997). A qualitative analysis of conflict types and dimensions in organizational groups. Administrative science quarterly, 530-557. https://doi.org/10.2307/2393737

Jetten, J., Spears, R., \& Manstead, A. S. (1998). Defining dimensions of distinctiveness: Group variability makes a difference to differentiation. Journal of Personality and Social Psychology, 74(6), 1481. https://doi.org/10.1037/0022-3514.74.6.1481

Klagegg, O. J., Samset, K., \& Magnussen, O. M. (2005). Improving Success in Public Investment Projects: Lessons from Government Initiative in Norway to Improve Quality at Entry. 19th IPMA World Congress.

Kotur, B. R., \& Anbazhagan, S. (2014). Education and work-experience-influence on the performance. Journal of Business and Management, 16(5), 104-110. https://doi.org/10.9790/487X-1653104110

Li, F., Li, Y., \& Wang, E. (2009). Task characteristics and team performance: The mediating effect of team member satisfaction. Social Behavior and Personality: an international journal, 37(10), 1373-1382. https://doi.org/10.2224/sbp.2009.37.10.1373

Liang, T.-P., Wu, J. C.-H., Jiang, J. J., \& Klein, G. (2012). The impact of value diversity on information system development projects. International Journal of Project Management, 30(6), 731-739. https://doi.org/10.1016/j.ijproman.2011.11.006

Lim, C. S., \& Mohamed, M. Z. (1999). Criteria of project success: An exploratory re-examination. International Journal of Project Management, 17(4), 243-248. https://doi.org/10.1016/S0263-7863(98)00040-4

Liu, A. M., \& Walker, A. (1998). Evaluation of project outcomes. Construction Management \& Economics, 16(2), 209-219. https://doi.org/10.1080/014461998372493

Lovelace, K., Shapiro, D. L., \& Weingart, L. R. (2001). Maximizing cross-functional new product teams' 
innovativeness and constraint adherence: A conflict communications perspective. Academy of Management Journal, 44(4), 779-793. https://doi.org/10.5465/3069415

Machlis, G. E., Force, J. E., \& Burch Jr, W. R. (1997). The human ecosystem part I: The human ecosystem as an organizing concept in ecosystem management. Society \& Natural Resources, 10(4), 347-367. https://doi.org/10.1080/08941929709381034

Milberg, C., \& Walsh, K. D. (2012). Exploring lean construction practice, research, and education. Engineering, Construction and Architectural Management.

Mugenda, O. M., \& Mugenda, G. (2003). Research Methods. Research Methods.

Ofori, D. F. (2013). Project management practices and critical success factors-A developing country perspective. International Journal of Business and Management, 8(21), 14. https://doi.org/10.5539/ijbm.v8n21p14

Rutterford, C., Copas, A., \& Eldridge, S. (2015). Methods for sample size determination in cluster randomized trials. International Journal of Epidemiology, 44(3), 1051-1067. https://doi.org/10.1093/ije/dyv113

Saunders, M., Lewis, P., \& Thornhill, A. (2003). Research methods for business students. Essex: Prentice Hall: Financial Times.

Tajfel, H., Turner, J. C., Austin, W. G., \& Worchel, S. (1979). An integrative theory of intergroup conflict. Organizational identity: A reader, 56(65), 9780203505984-16.

Van Niekerk, S. I., \& Steyn, H. (2011). Defining 'project success' for a complex project-The case of a nuclear engineering development. South African Journal of Industrial Engineering, 22(1), 123-136. https://doi.org/10.7166/22-1-38

Wi, H., \& Jung, M. (2010). Modeling and analysis of project performance factors in an extended project-oriented virtual organization (EProVO). Expert Systems with Applications, 37(2), 1143-1151. https://doi.org/10.1016/j.eswa.2009.06.051

Woehr, D. J., Arciniega, L. M., \& Poling, T. L. (2013). Exploring the effects of value diversity on team effectiveness. Journal of Business and Psychology, 28(1), 107-121. https://doi.org/10.1007/s10869-0129267-4

Yalegama, S., Chileshe, N., \& Ma, T. (2016). Critical success factors for community-driven development projects: A Sri Lankan community perspective. International Journal of Project Management, 34(4), 643-659. https://doi.org/10.1016/j.ijproman.2016.02.006

Zhang, X., Wu, Y., Shen, L., \& Skitmore, M. (2014). A prototype system dynamic model for assessing the sustainability of construction projects. International Journal of Project Management, 32(1), 66-76. https://doi.org/10.1016/j.ijproman.2013.01.009

\section{Copyrights}

Copyright for this article is retained by the author(s), with first publication rights granted to the journal.

This is an open-access article distributed under the terms and conditions of the Creative Commons Attribution license (http://creativecommons.org/licenses/by/4.0/). 